\title{
The Effect of Environmental Preservation, Advanced Technology, Hotel Image, and Service Quality on Guest Loyalty
}

\author{
Imran Almomani ${ }^{1}$, Mohammed Abdullah Nasseef ${ }^{2}$, Ra'ed Masa'deh $^{3}$, Fayez Bataine ${ }^{4} \&$ Ahmed Ayoub $^{4}$ \\ ${ }^{1}$ Department of Food and Beverage, Faculty of Tourism and Hospitality, The University of Jordan, Aqaba, Jordan \\ 2 Department of Business Administration, Faculty of Economics and Administration, King Abdulaziz University, \\ Jeddah, Saudi Arabia \\ ${ }^{3}$ Management Information Systems Department, School of Business, The University of Jordan, Amman, Jordan \\ ${ }^{4}$ Department of Hotel Management, Faculty of Tourism and Hotel Management, The University of Jordan, Aqaba, \\ Jordan \\ Correspondence: Ra'ed Masa'deh, Management Information Systems Department, School of Business, The \\ University of Jordan, Amman, Jordan. Tel: 962-3-209-0450. E-mail: r.masadeh@ju.edu.jo
}

Received: June 7, 2017

doi:10.5430/ijba.v8n4p49
Accepted: June 20, 2017

Online Published: June 27, 2017

URL: https://doi.org/10.5430/ijba.v8n4p49

\begin{abstract}
This paper aims at investigating the effects of environmental preservation, advanced technology, hotel image, and service quality on guest loyalty. A total of 193 questionnaire containing 48 items was used to collect information from guests in five-star hotels in Aqab city located in Jordan. Multiple regression analysis was conducted to test the research hypotheses. Results of the current study revealed that there is a significant impact of environmental preservation, hotel image, and service quality on guest loyalty, whereas advanced technology has no significant impact on it. The implications of these results to both theory and practice is discussed at the end of this paper.
\end{abstract}

Keywords: environmental preservation, advanced technology, hotel image, service quality, guest loyalty, Aqaba, Jordan

\section{Introduction}

In our present age, many factors contributed in the development of hospitality and tourism industry (Hamoud et al., 2016). Of the most important factors are the economic, cultural and social development and the increasing desirability of individuals to travel and navigate due to the availability of free tie and the tendency to participate in voluntary activities and getting acquainted with other civilizations, or this could be for medical treatment or education (Alshawagfih, et al., 2015). As a result of the great interest received by this sector from the world's governments which directly influenced the increase of the hotel activity, an intensive competition among tourist destinations to attract tourist urging those destinations to investigate the factors that affect the guests' behavior, try to realize their satisfaction and focus on the services the guests wish to have in order to enable the hotel facility to compete and share in the highest possible rate in the market (Al-Hussein, et al., 2015). Therefore, the quality of service received great attention from both the provider and receiver of the service. With the development of modern technology and international communication methods, many auditory, visual and written promotional campaigns were launched warning from the increasing aggression against natural resources and the consequences of this on planet earth and future generations. Accordingly, the customers' attention to the hotels which preserve the environment increased.

Moreover, the development in technology still has many reflections on the hospitality sector and competition has become strong among hotels to provide modern technological services to their clients concerning the control of service, security, safety and entertainment (Bazazo \& Alananzeh, 2016). All this creates positive reputation for the hotel and forms a mental image that makes customers speak positively about that hotel which is called (WOM) word of mouth. Because of the fast and continuous developments in the hospitality sector, it suffers difficulties in getting new customers for the multiple choices they have. This made the hotel establishment, or the tourist destination more generally, shift from the objective of attaining new customers as a secondary role, to keeping the present customers as long as possible as a main role through keeping up with the new and modern techniques, getting acquainted with 
the strategies of competitors and providing special programs that enhance loyalty and belonging to the hotel establishment and help to wide-spread its positive image internationally.

Considering the entry of big investments to Jordan during the past few years, especially in Aqaba governorate in the south of Jordan which is the only sea-port and part of the Jordanian golden triangle (Aqaba, Petra, Wadi Rum), it received attention in 2001 to be special economic developmental area exempted from customs fees. From that time on, Aqaba witnessed several huge tourist projects and the number of hotels and tourist facilities increased to become the second largest tourist city concerning the number of hotels and tourist establishments after the capital Amman, and as a result, there has been great competition between those hotels to gain the largest possible number of customers (Alananzeh, 2014). Therefore, this study has come to shed light on the loyalty of the guest and assessing it through the perspective of guests in different hotels in Aqaba city and also because of the scarcity of the researches which focused on studying the factors which affect the guest's loyalty to the hotel establishment in Jordan in general and its rarity in Aqaba city in particular. For that reason, this study sought to identify the loyalty of guests about the services of five - star hotels in the city of Aqaba.

This study aimed at recognizing the extent of care hotels give to the environmental aspect (Green Hotels) and also to Know the hotel's care for using developed technology to present it to customers, the extent to which a hotel gives attention to the quality of the products and services to customers and the degree of their response to the customers' demands. The main objective of this study is to assess the factors of guests' loyalty in several hotels in Aqaba concerning the care of the hotel for the environment and modern technology and quality and their impact on the hotel's reputation.

The importance of this study is in presenting practical recommendations to the hotel sector in Aqaba city based on the tourists' recognition to the most important factors that influence their satisfaction and create their loyalty to the hotel to improve the reputation of the hotel sector in Aqaba city in particular and the rest of the kingdom's regions in general. Since the realization of the guests' loyalty is the main key to success and noble competition and recognizing the reasons or factors that cause the loyalty of guests is the purpose of all service sectors including hotels and the reflection of this on the hotel's reputation and the role performed by the hotel sector in the national economy. Tourism industry has an effective role in providing work opportunities in Jordan as the statistics of Jordan Tourism Board indicated that the tourism sector in Jordan provided more than 50 thousand job opportunities in 2012 and that the workers in this sector exceeded 140 thousand, which means that about one million persons got benefit from the revenues of tourism sector (Jordan Tourism Board, 2012). The number of workers in the hotel sector in 2014, according to the statistics of the Ministry of Tourism and Antiquities, reached at 18644 and the number rose to 19058 in 2015 who are the direct workers in hotel sector (Ministry of Tourism and Antiquities, 2016).

\section{Literature Studies}

Hospitality institutions nowadays seek to present the best possible services to tourists in a way that exceeds the expectations and requirements of the tourists. Presenting the best is the key by which those hotel establishments achieve progress on the local, regional and international levels. The tourist has become the center of attention and concentration, the main factor which forms the marketing strategy and the hub of the entertaining process of the hotel institution (Oliver, 1999; Sasidharan, et al., 2002; Bazazo, et al., 2016a).

\subsection{Quality and Loyalty}

Hawkins, et al. (1995) and Griffin (1995) defined loyalty as the consumer's intention to buy the product or the service again or the tourist's intention to return to the hotel. This is usually connected to quality or emotional reasons. Many studies indicated that loyalty is an important indicator to the success of the hotel. When the customer returns to the hotel, this refers to the hotel, this refers to the success of the hotel in the market (Turnbull \& Wilson, 1989; Bauer, et al., 2002; Bigne \& Andreu, 2002; Yoon \& Uysal, 2005; Kim, et al., 2015). In a study conducted by (Loureiro \& Gonzales, 2008) about the effect of some factors in creating the loyalty of tourists in a visit to the rural areas, they pointed out the quality is the final judgment of the tourists on the service they received. This, accordingly, forms the impression or feeling of loyalty and the desire whether to repeat the visit or not. The study concluded that service quality has an effect and positive significance to the tourist in raising their loyalty to the tourist destination and a positive relationship between quality and the level of the tourist's satisfaction.

However, a number of researchers like (Oliver, 1980; Grönroos, 1990; Chiou, 2004; Alexandros \& Shabbar, 2005; McCleary, et al., 2006; Tsoukatos \& Rand, 2006; Bazazo, et al., 2016b) indicated that not only quality that creates the tourists loyalty but the confidence, quick response and safety are also important and sensitive factors in founding and creating the tourist's loyalty to the tourist destination in addition to the institution's reputation, the mental image 
of the hotel or the vision fancied by the tourist about a hotel or tourist destination. Loyalty differs due to culture that is loyalty is connected to the customer's culture and this was confirmed by the study of (Tsaur, et al., 2005) in comparing the loyalty of three different cultures concerning the quality of service and its connection to loyalty, as their study revealed the English tourists are more appreciative to quality than Asians and Europeans. Loyalty is the desire generated in the customer to return to the hotel or to transact several times with the service provider. This happens when the customer recognizes the economic benefit of the service they receive and which fulfilled their desires. In other meaning, loyalty is a psychological factor in the customer related to their receipt of high quality that positively affects their psychic (Bansal \& Taylor, 1999; Ranaweera \& Prabhu, 2003). Moreover, Butscher (2002) asserted that creating long-term loyalty does not necessarily depend on the materialistic aspect only but also on emotion, trust and partnership. Correspondingly, Geronikolas (2012) concentrated on the factors which alienate the tourist or customer from the hotel and mentioned untrained employees, lack of cleanliness, princes and quality of food and drink. Doubtless that applying the principles of comprehensive quality management in the hotel sector enhances the quality of the hotel services that should meet the requirements and expectations of tourists whether on the local or regional level (Bazazo \& Alananzeh, 2016).

\subsection{The Image and Reputation}

Assael (1987) defined "image" as the final or total recognition of the tourist destination or the hotel which formed over years through the accumulation of information directly or indirectly on the previous experiences. He also pointed out that image is the set of beliefs which formed a complete image for a destination or hotel. Chiu and Ananzeh (2012a, 2012b) argued that the cognitive image of the destaination has a great imact on the formation of the affective image nd the overall image. Martin \& Bosque (2008) defined it as a mental structure formed through selected impressions from a flow of impressions. The study presented by Back (2005) about the effect of "image" on the consumer's behavior after the purchase and its impact on the level of their satisfaction and loyalty to the hotel showed that the formulated image affected their satisfaction and loyalty. Tepeci (1999) also indicated that building a positive image of the hotel or service institution is a step on the right track to constitute a permanent loyalty under the service competition on the regional and international level, while (Han \& Hyun, 2012) pointed out that there is another loyalty which is the loyalty of the rich class to the fancy restaurants or Five -star hotels because those look for distinction.

\subsection{Advanced Technology}

Advanced technology affected tourism industry and caused an international revolution. It enabled the tourist to determine and classify the tourist products and services, so it affected the decision of purchase and played an important role in the service competition especially the electronic tourism and the internet supported the cooperation and interaction between the provider and receiver of the service and reorganized, developed and marketed the tourist service and tourist destination with complete concentration on what the tourist needs from advanced technological means (Buhalis \& O'Connor, 2005). While Ribbink, et al. (2004) referred to what is called (e-trust) where they explained what trust is closely connected to trust which in turn leads to satisfaction which constitutes loyalty, as the results of their study Showed close relationship between -e-trust and loyalty. In other meaning, as a result to e-trust, electronic loyalty appeared which is part of the direct loyalty resulted from the credibility of the electronic transaction and the electronic services the tourist receives before the purchase process or during his consumption to the service or product and the advanced technological means provided by the provider and which fulfill his desires and meet his needs (Reinartz \& Kumar, 2002). Jeng \& Fesenmaier (2002) asserted to collect information about the tourist destination before travelling and the purpose is to lessen the risks of selecting a destination that does not meet their need and for their decision to be correct.

In addition, the study conducted by (Leung, et al., 2013) indicates the important role of advanced technology in EWOM and in social communication, surfing websites, watching the films related to the product, making virtual visit to the tourist destination and getting acquainted with the electronic services presented by the hotel or the tourist destination. Smith (2000) stated that information program and advanced electronic devices are the most important program of the programs used by the hotel to enhance loyalty like service program, discount program and local programs and else from which advances technology is the most important.

\subsection{Green Hotels}

Green hotels are those which seek to be more suitable to the environment through the effective use of energy and rationalizing the use of water and resources in addition to providing excellent services. The environment friendly hotel is the one which presser the natural environment and lessens pollution which preserves the natural environment and lessens pollution as well as using organic material and optimal use of technology (Mensah, 2007). It provides the 
customers with instructions how to ideally use power without waste during their stay and it trains its employees on that and shares with the local society in preserving the environment and natural resources. Those hotels concentrate on using detergents that do not contain toxic materials, prevent smoking, focus on using renewable energy and recycle waste. Lee, et al. (2010) asserted that there has been general attention to the environment, and the first concern with hotels was to apply the governmental laws to preserve the environment, the alternative power and recycling for the financial benefit. The hotels concentrated on the environmental aspect to enhance the competitiveness in the hotel sector and their study affirmed the recognition, interaction and the comprehensive image of the tourist about green hotels. The results of the study showed that there is relationship between the comprehensive or total image and green hotels and its effect on the tourist behavior in terms of satisfaction and advising friends to stay in that satisfaction and advising friends to stay in that hotel. Various managements recognized the importance of green management in creating an image and loyalty with the customers and enhancing the market share of hotels which became the main part in the strategic and operational plan for most of the hotels in this age in most countries of the word (Butler, 2008; Alananzeh, 2017). The study of Kim \& Han (2010) revealed that there is awareness among tourist and that they have the desire to transact and cooperate with green hotels and to pay extra sums of money to stay in green hotels.

\section{Research Methodology}

This section provides the methodology applied in the current study. It consists of the research model, operational definitions of the study's independent and dependent variables, research hypotheses, besides data collection tool and research population and sample.

\subsection{Research Model}

The elements of this research are established based on preceding literature, either theoretically or empirically. Indeed, this study used variables that are common in hotel management literature. Figure 1 represents a model for the study that shows the independent variables, the dependent variable, and the proposed relationship between them.

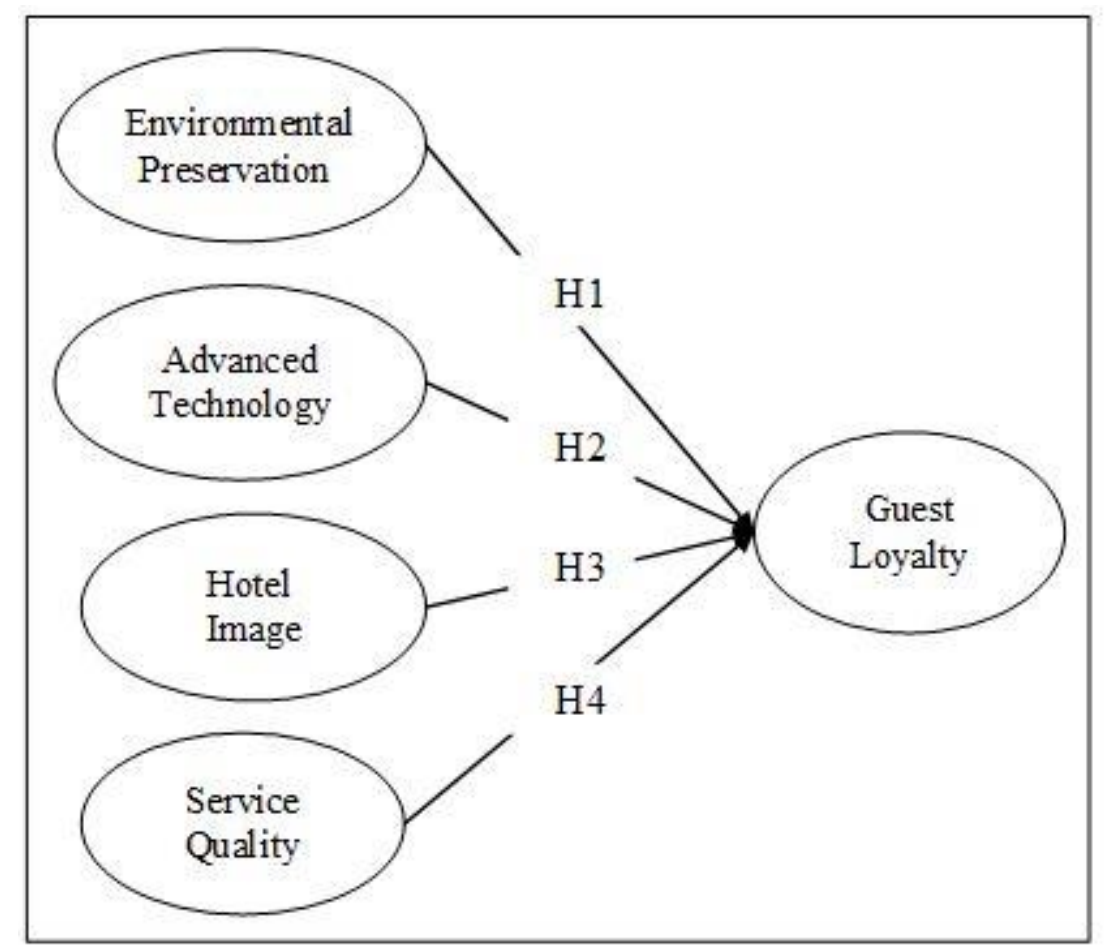

Figure 1. Research Model

\subsection{Operational Definitions}

Adapted from (Sasidharan, et al., 2002; Mensah, 2007; Chan, et al., 2017), the current research considers four 
independent variables namely environmental preservation, advanced technology, hotel image, and service quality. Guest loyalty, the dependent variable, is adapted from (Lee, et al., 2009; Breiby \& Slåtten, 2015; Kim, et al., 2015) and measured through seven items.

\subsection{Research Hypotheses}

In order to test the research model, the study is hypothesized as follows:

H1: There is a statistically significant impact of environmental preservation on guest loyalty.

H2: There is a statistically significant impact of advanced technology on guest loyalty.

H3: There is a statistically significant impact of hotel image on guest loyalty.

H4: There is a statistically significant impact of service quality on guest loyalty.

\subsection{Population and Sampling}

The targeted population of this study consisted of five star hotels in Aqaba city in Jordan. However, 206 survey questionnaires were returned from respondents and considered 193 after eliminating the incomplete ones. The primary data was collected through a drop-and-collect survey technique. The surveys were distributed to the receptionist employees working in these hotels that agreed to participate in the study. The questionnaire consisted of two sections; the first section in questionnaire presents general personal information about a respondent, the gender, age, academic level, employement status, travel reasons, and which hotel do they prefer to stay in. The second section includes questions to measure the independent and dependent variables based on their operational definitions.

\section{Data Analysis and Results}

In order to explore the impact of environmental preservation, advanced technology, hotel image, and service quality on guest loyalty, in which these variables have been measured using 5-points Likert scale that varies between strongly disagree $=1$ and strongly agree $=5$. Also, reliability and validity analyses were conducted, descriptive analysis was used to describe the characteristic of sample and the respondent to the questionnaires besides the independent and dependent variables. Furthermore, a multiple regression analysis was employed to test the research hypotheses.

\subsection{Validity and Reliability}

Validity and reliability are two important measures to determine the quality and usefulness of the primary data. Validity is about accuracy and whether the instrument measures what it is intended to measure while reliability is about precision; it is used to check the consistency and stability of the questionnaire. Indeed, the researchers depended on scales and items that were previously developed and used by other researchers with similar interest. Also a draft of the questionnaire was formulated, and then it was reviewed by four academic lecturers-who have a sufficient knowledge and experience in this scope- to insure that each item is measuring what is intended to be measured, and to avoid the ambiguity and complexity in the phrasing of questions. The reliability of the instrument was measured by the Cronbach's alpha coefficient. Further, some scholars (e.g. Bagozzi \& Yi, 1988) suggested that the values of all indicators or dimensional scales should be above the recommended value of 0.60 . Table 1 represents the results of Cranach's alpha for the independent and dependent variables. Cronbach's alpha coefficients of all the tested variables are above 0.60 which suggesting the composite measure is reliable.

Table 1. The Cronbach's alpha coefficients of study variables

\begin{tabular}{lll}
\hline Variables & Number of items & Cronbach alpha \\
\hline Environmental preservation & 13 & 0.930 \\
\hline Advanced technology & 6 & 0.847 \\
\hline Hotel image & 8 & 0.927 \\
\hline Service quality & 15 & 0.947 \\
\hline Guest loyalty & 6 & 0.931 \\
\hline
\end{tabular}

\subsection{Respondents Demographic Profile}

As indicated in Table 2, the demographic profile of the respondents for this study showed that they are typically males from Jordan, most of them less than 30 years old, the majorities hold bachelor degrees; most of them earn less 
than 1000 \$ monthly; came to Aqaba city for leisure purposes, and the majorities prefere Movenpick and Intercontinental Hotels respectively.

Table 2. Description of the respondents' demographic profiles

\begin{tabular}{|c|c|c|c|}
\hline Category & Category & Frequency & Percentage \% \\
\hline \multirow[t]{3}{*}{ Gender } & Males & 103 & 53.4 \\
\hline & Females & 90 & 46.6 \\
\hline & Total & 193 & 100 \\
\hline \multirow[t]{5}{*}{ Age } & 18 years - less than 25 & 119 & 61.6 \\
\hline & 25 years - less than 30 & 45 & 23.3 \\
\hline & 30 years - less than 40 & 25 & 13.0 \\
\hline & More than 40 years old & 4 & 2.1 \\
\hline & Total & 193 & 100 \\
\hline \multirow[t]{8}{*}{ Education level } & Less than high school & 14 & 7.3 \\
\hline & High school graduate & 24 & 12.4 \\
\hline & Diploma & 17 & 8.8 \\
\hline & Trade/technical/vocational certificate & 20 & 10.4 \\
\hline & Bachelor & 106 & 54.9 \\
\hline & Master & 10 & 5.2 \\
\hline & Doctorate & 2 & 1.0 \\
\hline & Total & 193 & 100 \\
\hline \multirow{4}{*}{$\begin{array}{l}\text { Personal income }(\$) \\
\text { monthly }\end{array}$} & Less than 500 & 79 & 40.9 \\
\hline & 500- less than 1000 & 83 & 43.0 \\
\hline & More than 1000 & 31 & 16.1 \\
\hline & Total & 193 & 100 \\
\hline \multirow[t]{4}{*}{ Nationality } & Jordanian & 120 & 62.2 \\
\hline & Arabic & 35 & 18.1 \\
\hline & Overseas & 38 & 19.7 \\
\hline & Total & 193 & 100 \\
\hline \multirow[t]{6}{*}{ Employment status } & Manager & 43 & 22.3 \\
\hline & Self-employed & 70 & 36.3 \\
\hline & Technician, nursing, etc & 40 & 20.7 \\
\hline & Student & 13 & 6.7 \\
\hline & Doctor, lawyer, or teacher & 27 & 14.0 \\
\hline & Total & 193 & 100 \\
\hline \multirow[t]{3}{*}{ Travel reason } & Conferences and exhibitions & 67 & 34.7 \\
\hline & Leisure & 126 & 65.3 \\
\hline & Total & 193 & 100 \\
\hline \multirow[t]{6}{*}{ Hotel residency } & Double Tree/Helton & 37 & 19.2 \\
\hline & Movenpick & 53 & 27.5 \\
\hline & Kimpensky & 32 & 16.6 \\
\hline & Oryx & 25 & 13.0 \\
\hline & Intercontinental & 46 & 23.7 \\
\hline & Total & 193 & 100 \\
\hline
\end{tabular}




\subsection{Descriptive Analysis}

In order to describe the responses and thus the attitude of the respondents toward each question they were asked in the survey, the mean and the standard deviation were estimated. While the mean shows the central tendency of the data, the standard deviation measures the dispersion which offers an index of the spread or variability in the data (Sekaran \& Bougie, 2013). In other words, a small standard deviation for a set of values reveals that these values are clustered closely about the mean or located close to it; a large standard deviation indicates the opposite. The level of each item was determined by the following formula: (highest point in Likert scale - lowest point in Likert scale) / the number of the levels used $=(5-1) / 5=0.80$, where 1-1.80 reflected by "very low", 1.81-2.60 reflected by "low", 2.61-3.40 reflected by "moderate", 3.41-4.20 reflected by "high", and 4.21-5 reflected by "very high". Then the items were being ordered based on their means. Tables 3 and 4 show the results.

Table 3. Overall mean and standard deviation of the study's variables

\begin{tabular}{llllll}
\hline $\begin{array}{l}\text { Type } \\
\text { Variable }\end{array}$ & Variables & Mean & Standard Deviation & Level & Order \\
\hline $\begin{array}{l}\text { Independent } \\
\text { Variables }\end{array}$ & Environmental preservation & 3.8473 & 0.86597 & High & 3 \\
\hline \multicolumn{1}{r}{} & Advanced technology & 3.7176 & 0.91485 & High & 4 \\
\hline & Hotel image & 3.9631 & 0.79345 & High & 1 \\
\hline $\begin{array}{l}\text { Dependent } \\
\text { Variable }\end{array}$ & Service quality & 3.8974 & 0.74616 & High & 2 \\
\hline
\end{tabular}

As presented in Table 3, data analysis results have shown that guests' hotel image in the five-star hotels in Aqaba city located in Jordan is applied to a high level in which the mean score is 3.96, followed by variables of service quality, environmental preservation, and advanced technology; whereas guest loyalty is applied to a greater extent with a mean of 4.14. Table 4 demonstrates the mean, standard deviasion, level, and order scores for the items for each variable.

Table 4. Mean and standard deviation of the study's variables

\begin{tabular}{lllll}
\hline Environmental preservation & Mean & SD & Level & Order \\
\hline The hotel defines special smoking places & 4.35 & 1.061 & $\begin{array}{l}\text { Very } \\
\text { high }\end{array}$ & 1 \\
& & & 4 \\
\hline $\begin{array}{l}\text { The hotel uses posters in the rooms to explain the hotel 's policy towards the } \\
\text { preservation of the environment }\end{array}$ & 4.01 & 1.099 & High & 4.84 \\
\hline The hotel offers guests bulletins awareness of energy conservation & 1.203 & High & 6 \\
\hline The hotel uses posters for environment & 3.76 & 1.189 & High & 8 \\
\hline $\begin{array}{l}\text { The hotel uses automatic systems for energy management in the rooms such as } \\
\text { card system }\end{array}$ & 4.10 & 1.085 & High & 2 \\
\hline $\begin{array}{l}\text { The hotel uses a special controller for the heating and cooling system to ensure } \\
\text { control of vacant rooms }\end{array}$ & 4.08 & 1.075 & High & 3 \\
\hline Administration encourages and participates initiatives to protect the environment & 3.71 & 1.224 & High & 9 \\
\hline $\begin{array}{l}\text { Administration provides customers with information on how to preserve the } \\
\text { environment }\end{array}$ & 3.65 & 1.159 & High & 12 \\
\hline The hotel puts posters on environmental products & 3.69 & 1.277 & High & 10 \\
\hline The hotel uses natural products and healthy foods & 3.66 & 1.236 & High & 11 \\
\hline There are lush gardens surrounding the hotel & 3.88 & 1.143 & High & 5 \\
\hline The hotel uses recycle cans and empty bottles systems & 3.46 & 1.299 & High & 13 \\
\hline The hotel uses the devices energy-saving lighting & 3.83 & 1.198 & High & 7 \\
\hline Advanced technology & Mean & SD & Level & Order \\
\hline
\end{tabular}


The hotel uses robots in the room service

3.29

1.561

Moder 6

ate

The hotel uses technology developments in the rooms

3.61

3.79

The hotel uses advanced technology in the public safety and security

The hotel use IT system on room control

The hotel uses technology to entertain guests

Modern electronic devices are available in the hotel

3.58

3.67

$4.37 \quad 0.932 \quad$ Very

1.186

High

1.186 High 4

1.137

High

1.153 High 5

$67 \quad 1.234$

Hotel image

The hotel has a good reputation that make guests comfortable in dealing with them

The arrangement and interior design of the hotel are attractive

The hotel building is attractive

The hotel management ensures to employ a skilled staff

The hotel management pursues the complaints of guests and provides appropriate solutions

\begin{tabular}{|c|c|c|c|c|}
\hline The hotel is committed to providing guests services on time & 3.91 & 0.947 & High & 4 \\
\hline The presence of hotel's director does exist consistently among the hotel guests & 3.75 & 1.042 & High & 7 \\
\hline World series that owns the hotel & 3.89 & 1.040 & High & 5 \\
\hline Service quality & Mean & SD & Level & Order \\
\hline The hotel offers the services required to achieve the satisfaction of guests & 4.15 & 0.968 & High & 1 \\
\hline $\begin{array}{l}\text { The hotel has the ability to complete the services, serviced accurately and } \\
\text { confidently to achieve satisfaction for guests }\end{array}$ & 3.97 & 0.869 & High & 3 \\
\hline $\begin{array}{l}\text { The workers at the hotel have the know-how and competence in dealing with the } \\
\text { guests and to respond to them }\end{array}$ & 3.91 & 0.928 & High & 5 \\
\hline You got what hotel has promised to offer & 3.85 & 0.995 & High & 9 \\
\hline There is noticible concern for persons with special needs and the elderly & 3.88 & 1.001 & High & 6 \\
\hline The services provided by the hotel are confidently & 3.88 & 1.008 & High & 6 \\
\hline $\begin{array}{l}\text { The is a strong interest by the staff of the hotel towards permanent hotel } \\
\text { customers }\end{array}$ & 3.98 & 0.941 & High & 2 \\
\hline The workers in the hotel are truthful in dealing with guests & 3.92 & 0.984 & High & 4 \\
\hline The hotel offers incentives and rewards programs for its customers & 3.79 & 1.020 & High & 11 \\
\hline The hotel offers a safe transfer by credit card process & 3.86 & 0.977 & High & 8 \\
\hline Employees who provide services have the required skill and professionalism & 3.85 & 0.946 & High & 9 \\
\hline The staff were kind and enjoy the spirit of friendship & 3.87 & 0.999 & High & 7 \\
\hline The hotel confirms to respect the privacy of customers & 3.85 & 1.017 & High & 9 \\
\hline The presence of the female element of staff does exist & 3.82 & 1.047 & High & 10 \\
\hline The hotel provides comfortable bed and headrest & 3.87 & 1.045 & High & 7 \\
\hline Guest loyalty & Mean & SD & Level & Order \\
\hline I will be a permanent customer in the future of this hotel & 4.21 & 1.030 & $\begin{array}{l}\text { Very } \\
\text { high }\end{array}$ & 2 \\
\hline I will continue as a customer to this hotel even if it raises prices & 3.93 & 1.100 & High & 6 \\
\hline I will speak positively about this hotel & 4.38 & 0.956 & $\begin{array}{l}\text { Very } \\
\text { high }\end{array}$ & 1 \\
\hline I will encourage friends and relatives to be customers of this hotel & 4.16 & 0.968 & High & 3 \\
\hline The provided services from this hotel deserve the amount I pay & 4.08 & 1.012 & High & 5 \\
\hline I will always enjoy staying at this hotel & 4.13 & 1.089 & High & 4 \\
\hline
\end{tabular}




\subsection{Hypotheses Testing Results}

The current research is mainly seeking to investigate the impact of environmental preservation, advanced technology, hotel image, and service quality on guest loyalty of guests in the five-star hotels in the city of Aqaba. Consequently, in order to test the hypotheses developed for this study, multiple regression technique was used. Further, the level of significance ( $\alpha$-level) was chosen to be 0.05 and the probability value (p-value) obtained from the statistical hypotheses test is considered to be the decision rule for rejecting the null hypotheses (Creswell, 2009). If the p-value is less than or equal to $\alpha$ - level, the null hypothesis will be rejected and the alternative hypothesis will be supported. However, if the p-value is greater than the $\alpha$-level, the null hypothesis cannot be rejected and the alternative hypothesis will not be supported. In addition, normality of the independent variables and the absence of multi co-linearity problem (a case of multiple regression in which the independent variables are themselves highly correlated) were checked. According to Pallant (2005), most of the values should be inside the adequate ranges for normality (i.e. -1.0 to +1.0 ). For this purpose, skewness and Variance Inflation Factor (VIF) were investigated; Table 5 includes the results.

Table 5. Skewness and VIF for the independent variables

\begin{tabular}{llll}
\hline Variables & Tolerance & VIF & Skewness \\
\hline Environmental preservation & 0.718 & 1.393 & -1.021 \\
\hline Advanced technology & 0.728 & 1.374 & -0.677 \\
\hline Hotel image & 0.482 & 2.075 & -1.020 \\
\hline Service quality & 0.524 & 1.907 & -0.734 \\
\hline
\end{tabular}

As can be noticed from Table 5, the skewness values were within the normal values $(-1.0$ to +1.0$)$ suggesting that the data of the independent variables is normal. The VIF values were less than the critical value (10) which is most common among the most studies, suggesting no multi co-linearity problem among the independent variables. However, the results of testing the four hypotheses are demonstrated in Table 6.

Table 6. Result for the study model (b)

\begin{tabular}{llllllll}
\hline Variable & $\mathbf{r}$ & $\mathbf{R}^{2}$ & $\mathbf{f}$ & Sig (f) & $\boldsymbol{\beta}$ & $\mathbf{t}$ & Sig (t) \\
\hline Environmental preservation & 0.655 & 0.429 & 35.246 & $0.000 \mathrm{a}$ & 0.383 & 4.354 & 0.000 \\
Advanced technology & & & & & 0.026 & 0.399 & 0.690 \\
Hotel image & & & & & 0.318 & 3.999 & 0.000 \\
Service quality & & & & & 0.207 & 2.713 & 0.007 \\
\hline
\end{tabular}

a. Predictors: (Constant), Environmental preservation, Advanced technology, Hotel image, Service quality

b. Dependent variable: Guest loyalty

Refer to Table 6 the multiple correlation coefficient $\mathrm{R}=0.655$ indicates that there is a strong positive correlation between the independent variables (environmental preservation, advanced technology, hotel image, and service quality) and guest loyalty. The R2 indicated the generalizability of the model. It allows us to generalize the results taken from the respondents to the whole population. In this case it equals 0.429 . The results showed that F-ratio for these data is equal to 35.246 , which is statistically significant at $p<0.05$. Therefore, we conclude that there is a statistically significant impact of the independent variables on guest loyalty.

The $\beta$ indicates the individual contribution of each predictor (independent variable) to the model, if other predictors are held constant. Table 6 shows the standardized coefficients for each independent variable. The values of $\beta$ for environmental preservation, hotel image, and service quality are $0.383,0.318$, and 0.207 respectively; and are positive. While for advanced technology, the value of $\beta$ is 0.026 which has a small value compared with other predictors. The level of effect of these variables depends on the $\beta$ value, the higher $\beta$ value the higher effect on dependent variable. We can infer from the values of beta that environmental preservation has the highest contribution in the model, followed by hotel image, and then service quality. 


\section{Discussion and Conclusions}

The aim of this study is to investigate the effects of environmental preservation, advanced technology, hotel image, and service quality on guest loyalty. The results emphasize the importance of all these constructs on creating customers' loyalty and have important implications for marketers and tourism stakeholders in Aqaba city. Most factors that shape and form guest's loyalty may be controlled, created, and improved by hoteliers.

The image of the hotel found to be the most important construct in loyalty to that hotel according to the respondents opinions. The company that insists on branding and marketing its image will generate high profit when reach the good unsuspected reputation. The hotel has a good reputation that makes guests comfortable in dealing with. The image of the hotel is consisted of many layers that form the holistic image of that hotel. The professional skillful employees, the interior design of the hotel, the attractiveness of the building and the surrounding area, serving guests on time and the fast respond to their complains, and the presence of the manager and supervisors among the hotel guests are some of the image layers that construct the overall image of the hotel which is an important part in creating guests loyalty and increases hotel's market share and revenue. These findings are constant with the results of Kandampully \& Suhartanto (2000) who claimed that hotel image and customer satisfaction are important factors in determining customer loyalty.

The findings of the study also pointed out the respondents claimed that service quality is critical in shaping guests' loyalty. Previous studies stated that service quality is connected with guests' satisfaction. Staff should give strong interest toward hotel permanent guests; they should be serviced accurately and confidently to achieve their satisfaction. Employees, in hotel industry, should work on building mutual trust with their customers through understanding different cultures in order to understand and how to deal with each one according to customers' own culture. It is the responsibility of the management to offer their employees a comprehensive and advanced training courses focused on cultures existed in the globe. The staff should be kind and enjoy the spirit of friendship. In addition, service quality includes the concern towards kids and persons with special needs and the elderly. ALsarayreh, et al. (2011) and Jayawardena, et al. (2013) insisted on the importance of the overall service quality in hotel's innovation and sustainability- driven management strategy.

Findings also revealed that hotel guests are keen to towards environmental preservation. Therefore, the hotel should define special smoking places, automatic systems for energy management in the rooms such as card system, a special controller for the heating and cooling system, and energy-saving lighting should be used, green gardens surrounding the hotels should increased which makes guests' staying comfortable. Guests who are empathized with nature are looking for green hotels that offer natural products and healthy foods, launch participates initiatives to protect the environment, recycle cans and empty bottles systems, and that puts posters on environmental products. Moreover, hotels that provide modern electronic devices are among hotels that attract tourists. Tourists who became experts in travel and hotel reservation are mostly looking for those hotels that uses advanced technology in the public safety and security, technology to entertain guests, and the developed technology in the rooms. But results showed that tourists ranked advanced technology factor as the least important factor in customer loyalty. Furthermore, several researchers consider the information systems and in particular the information technology (IT) and its flexibility as an enabler to achieve the desired competitive advantages, and as a crucial support to operational and strategic business decisions (Al Azmi, et al., 2012; Alenezi, et al., 2015; Alkalha, et al., 2012; Almajali \& Tarhini, 2016; Altamony et al., 2012; Kateb, et al., 2015; Maqableh \& Karajeh, 2014; Masa'deh, 2012, Masa'deh, et al., 2016; Obeidat, et al., 2013; Shannak, et al., 2010, Tarhini et al., 2016; Vratskikh et al., 2016); thus further research is required to examine the role of such IT applications in enhancing the managerial decisions. In addition, scholars (e.g. Masa'deh, et al. 2008; Hunaiti, et al., 2009; Masa'deh \& Kuk, 2009; Alshurideh, et al., 2012; Hajir, et al., 2015; Kannan \& Gharibeh, 2013; Masa'deh \& Shannak, 2012; Masa'deh, et al. 2013; Masa'deh, et al. Masa'deh, et al. 2017; Obeidat, et al., 2012, 2016; Shannak \& Alkour, 2012; Tarhini, et al., 2015a, 2015b) emphasize the need for large firms to integrate their IT systems with their KM strategies and processes in order to survive in their highly competitive business environments, which in turn could accelerate the managerial decisions as well.

In conclusion, this study highlighted the importance of environmental preservation and image in creating and enhancing customer loyalty. The results of the hypotheses testing revealed that there is a strong relationship between environmental preservation systems applied in the hotel and guest's intention to revisit, to recommend, and exhibit loyalty. Also, results showed that hotel image and service quality are important predictors of guest loyalty. But results of the hypotheses testing showed that advanced technology had no impact on guest loyalty. This could be justified that travellers nowadays are using their own smart phones which offers them all information and services they need. The competition between IT companies is fierce and has no limits or borders. These companies are trying 
to provide their customers with everything covering all aspects of life.

\section{References}

Abbasi, M. S., Elyas, T., \& Shah, F. (2015). Impact of individualism and collectivism over the individual's technology acceptance behaviour: A multi-group analysis between Pakistan and Turkey. Journal of Enterprise Information Management, 28(6), 747-768. https://doi.org/10.1108/JEIM-12-2014-0124

Al Azmi, N., Al-Lozi, M., Al-Zu'bi, Z., \& Dahiyat, S., (2012). Patients Attitudes toward Service Quality and its Impact on their Satisfaction in Physical Therapy in KSA Hospitals. European Journal of Social Sciences, 34(2), 300-314.

Alananzeh, O.A. (2014). Exploring the Factors Influencing Students in Enrolling Tourism and Hospitality Management Colleges in Jordan: A Case Study in Aqaba Economic Zone. Journal of Management Research, $6(2), 11-23$.

Alananzeh, O.A. (2017). Impact of Safety Issues and Hygiene Perceptions on Customer Satisfaction: A Case Study of Four and Five Star Hotels in Aqaba, Jordan. Journal of Tourism Research \& Hospitality, 6(1), 5-18.

Al-Badi, A., \& Al-Sawaei, S. (2017). Utilizing Social Media to Encourage Domestic Tourism in Oman. International Journal of Business and Management, 12(4), 84-94. https://doi.org/10.5539/ijbm.v12n4p84

Al-Badi, A., \& Al-Kaaf, W. (2017). Financial Incentives for Adopting Cloud Computing in Higher Educational Institutions. Asian Social Science, 13(4), 162-174. https://doi.org/10.5539/ass.v13n4p162

Al-Badi, A. H., \& Al-Qayoudhi, W. S. (2014). Adoption of social networks in business: Study of users and potential users in Oman. The International Business \& Economics Research Journal (Online), 13(2), 401-415.

Al-Dmour, R., \& Obeidat, B. (2015). Strategic IT-Business Alignment as Managers' Explorative and Ecploitative Strategies. European Scientific Journal, 11(7), 437-457.

Al-Dmour, H., Al-Madani, S., Alansari, I., \& Al-Dmour, R. (2016). Factors Affecting the Effectiveness of Cause-Related Marketing Campaign: Moderating Effect of Sponsor-Cause Congruence. International Journal of Marketing Studies, 8(5), 114-127. https://doi.org/10.5539/ijms.v8n5p114

Alenezi, H., Masa'deh, R. Alalwan, A., \& Al-Qirim, N. (2017). Factors Affecting e-Government Adoption in Kuwait: A Qualitative study. Electronic Journal of e-Government, 15(2), 84-102.

Alenezi, H., Tarhini, A., \& Masa'deh, R. (2015). Investigating the Strategic Relationship between Information Quality and E-Government Benefits: A Literature Review. International Review of Social Sciences and Humanities, 9(1), 33-50.

Alexandros A., \& Shabbar, J. (2005). Stated Preferences for Two Cretan Heritage Attractions. Annals of Tourism Research, 32(4), 985-1005. https://doi.org/10.1016/j.annals.2005.01.004

Al-Hussein, M.A., Jawabreh, O.A., Alananzeh, O.A., \& Ali, M.M. ( 2015). The Impact of Understanding the Behavior of Workers on the Success of Management (A Case Study of Five Star Hotels in Aqaba). Journal of Management Research, 7(3), 51-70.

Alkalha, Z., Al-Zu'bi, Z., \& Alshurideh, M. (2012). Investigating the Effects of Human Resource Policies on Organizational Performance: An Empirical Study on Commercial Banks Operating in Jordan. European Journal of Economics, Finance and Administrative Sciences, 51, 44-64.

Allam, M., \& Elyas, T. (2016). Perceptions of Using Social Media as an ELT Tool among EFL Teachers in the Saudi Context. English Language Teaching, 9(7), 1-9. https://doi.org/10.5539/elt.v9n7p1

Almajali, D., \& Tarhini, A. (2016). Antecedents of ERP Systems Implementation Success: A Study on Jordanian Healthcare Sector. Journal of Enterprise Information Management, 29(4), 549-565.

Al-Qirim, M., Rouibah, K., Serhani, M. A., Yammahi, A. R., \& Yammahi, M. A. (2017). Towards a Personality Understanding of Information Technology Students and their IT Learning in UAE University. Education and Information Technologies, 1-12. https://doi.org/10.1007/s10639-017-9578-1

Al-Qirim, N., Rouibah, K., Serhani, M. A., Yammahi, A. R., \& Yammahi, M. A. (2017). Learning Orientations of IT Higher Education Students in UAE University. Education and Information Technologies, 1-14. https://doi.org/10.1007/s10639-017-9589-y

Al-Qirim N., Tarhini, A., Rouibah, K. (2017). Determinants of Big Data Adoption and Success. In International Conference on Communications and Future Internet (ICCFI 2017). Jeju Island, South Korea, 10-13 August.

Alqahtani, M. A., Al-Badi, A. H., \& Mayhew, P. J. (2012). The Enablers and Disablers of E-Commerce: Consumers' 
Perspectives. The Electronic Journal of Information Systems in Developing Countries, 54(1), 1-25.

Alrowwad, A., \& Aqqad, N. (2017). The impact of transformational leadership on organizational performance via the mediating role of corporate social responsibility: A structural equation modeling approach. International Business Research, 10(1), 199-221. https://doi.org/10.5539/ibr.v10n1p199

Alsarayreh, M., Jawabreh, O., ALkharabsheh, K., \& Aldahamsheh, M. (2011). Tourism Promotion through the Internet (Websites):(Jordan as a Case Study). Asian Social Science, 7(6), 125-135. https://doi.org/10.5539/ass.v7n6p125

Alshawagfih, K.F., Alananzeh, O.A., \& Jawabreh, O.A. (2015). The Foundations of Selecting Cultural Tourism Product in Jordan. European Scientific Journal, 11(29), 198-217.

Alshurideh, M., \& Alkurdi, B. (2012). The Effect of Customer Satisfaction on Customer Retention in the Jordanian Mobile Market: An Empirical Investigation. European Journal of Economics, Finance and Administrative Sciences, 47, 69-78.

Altamony, H., Alshurideh, M., \& Obeidat, B. (2012). Information Systems for Competitive Advantage: Implementation of an Organizational Strategic Management Process. Proceedings of the 18th IBIMA Conference on Innovation and Sustainable Economic Competitive Advantage: From Regional Development to World Economic, Istanbul, Turkey, 9th-10th May.

Altamony, H., Al-Salti, Z., Gharaibeh, A., \& Elyas, T. (2016). The relationship between Change Management Strategy and Successful Enterprise Resource Planning (ERP) Implementations: A Theoretical Perspective. International Journal of Business Management and Economic Research, 7(4), 690-703.

Assael, H. (1987). Consumer Behavior and Marketing (3rd ed.). Boston: PWS-Kent.

Back, K.J. (2005). The Effects of Image Congruence on Customers' Brand Loyalty in the Upper Middle-Class Hotel Industry. Journal of Hospitality \& Tourism Research, 29(4), 448-467. https://doi.org/10.1177/1096348005276497

Bagozzi, R., \& Yi, Y. (1988). On the Evaluation of Structural Evaluation Models. Journal of the Academy of Marketing Science, 16(1), 74-94. https://doi.org/10.1007/BF02723327

Bansal, H.S., \& Taylor, S.F. (1999). The Service Provider Switching Model (SPSM): A Model of Consumer Switching Behaviour in the Service Industry. Journal of Service Research, 2(2), 200-218.

Bauer, H., Mark, G., \& Leach, M. (2002). Building Customer Relations over the Internet. Industrial Marketing Management, 31(2), 155-163. https://doi.org/10.1016/S0019-8501(01)00186-9

Bazazo, I. B., \& Alananzeh, O.A. (2016). The Effect of Electronic Tourism in Enabling the Disabled Tourists to Communicate with the Touristic and Archaeological Sites Case Study-Jordan. European Scientific Journal, 12(5), 111-128.

Bazazo, I. B., \& Alananzeh, O.A., Adas, K., \& Alshawagfih, K. F. (2016a). The Role of the Transformational Leadership in Enhancing the Social Responsibility at the Five Stars Hotels in the Hashemite Kingdom of Jordan. European Journal of Business and Management, 8(23), 67-74.

Bazazo, I. B., Alananzeh, O.A., \& Taani, A.A. (2016b). Marketing the Therapeutic Tourist Sites in Jordan Using Geographic Information System. European Journal of Business and Management, 8(30), 29.

Bisharat, H., Alrowwad, A., \& Mukattash, I. (2017). The Effect of Human Resource Management Practices on Organizational Commitment in Chain Pharmacies in Jordan. International Journal of Business and Management, 12(1), 50-67. https://doi.org/10.5539/ijbm.v12n1p50

Breiby, M.A., \& Slåtten, T. (2015). The Effects of Aesthetic Experiential Qualities on Tourists` Positive Emotions and Loyalty: A Case of a Nature-Based Context in Norway. Journal of Quality Assurance in Hospitality \& Tourism, 16(4), 323-346. https://doi.org/10.1080/1528008X.2015.1016591

Buhalis, D., \& O'Connor, P. (2005). Information Communication Technology Revolutionizing Tourism. Tourism Recreation Research, 30(3), 7-16. https://doi.org/10.1080/02508281.2005.11081482

Butler, J. (2008). The Compelling "Hard Case" for "Green" Hotel Development. Cornell Hospitality Quarterly, 49(3), 234-244.

Butscher, A.S. (2002). Customer Clubs and Loyalty Programmes. Abingdon, Oxon, GBR: Gower Publishing Limited.

Chan, E.S.W., Okumus, F., \& Chan, W. (2017). The Applications of Environmental Technologies in Hotels. Journal 
of Hospitality Marketing \& Management, 26(1), 23-47. https://doi.org/10.1080/19368623.2016.1176975

Chiou, J. S. (2004). The Antecedents of Consumers' Loyalty toward Internet Service Providers. Information \& Management, 41(6), 685-695. https://doi.org/10.1016/j.im.2003.08.006

Chiu, L. K., \& Ananzeh, O. A. (2012a). Evaluating the Relationship between the Role of Promotional Tools in MICE Tourism and the Formation of the Touristic Image of Jordan. Academica Turistica -Tourism and Innovation Journal, 5(1), 59-73.

Chiu, L. K., \& Ananzeh, O. A. (2012b). The role of MICE Destination Attributes on Forming Jordan Touristic Image. Academic Research International, 3(1), 267-277.

Creswell, J. (2009). Research Design: Qualitative, Quantitative, and Mixed Methods Approaches (3rd ed.). Thousand Oaks: Sage Publications.

El-Masri, M., \& Tarhini, A. (2017). Factors affecting the adoption of e-learning systems in Qatar and USA: Extending the Unified Theory of Acceptance and Use of Technology 2 (UTAUT2). Educational Technology Research and Development, 65(3), 743-763. https://doi.org/10.1007/s11423-016-9508-8

El-Masri, M., \& Tarhini, A. (2015). A Design Science Approach to Gamify Education: From Games to Platforms. Twenty-Third European Conference on Information Systems (ECIS), Münster, Germany. 26-29 May 2015

El-Masri, M., Orozco, J., \& Tarhini, A. (2015). The Impact of IS-Business Alignment Practices on Organizational Choice of IS-Business Alignment Strategies. The 19th Pacific Asia Conference on Information Systems (PACIS 2015), Paper 215, Singapore, 6-9 July 2015.

Elyas, T., \& Picard, P. (2012). Teaching and Moral Tradition in Saudi Arabia: A Paradigm of Struggle or Pathway towards Globalization?. Procedia - Social and Behavioral Sciences, 41, 1083-1086. https://doi.org/10.1016/j.sbspro.2012.06.782

Fedai, L., Daglı, G., Altınay, Z., \& Altınay, F. (2017). The examination of occupational burnout and job satisfaction of the physical education teachers. International Journal of Economic Perspectives, 11(1), 12-26.

Geronikolas, N. (2012). Customer Defects in the Hotel Industry: The Five (5) Most Common Factors Driving Business Away. Hub Pages Inc.

Griffin, J. (1995). Customer Loyalty: How to Earn it and How to Keep it. New York: Lexington Books.

Grönroos, C. (1990). Service Management and Marketing: Managing the Moments of Truth in Service Competition. Lexington, MA: Lexington Books \& Macmillan, Inc.

Hajir, J., Obeidat, B., \& Al-dalahmeh, M. (2015). The Role of Knowledge Management Infrastructure in Enhancing Innovation at Mobile Telecommunication Companies in Jordan. European Journal of Social Sciences, 50(3), 313-330.

Hamoud, M., Akour, M. A. \& Al-Salti, Z. (2016). Developing the Main Knowledge Management Process via Social Media in the IT Organisations: A Conceptual Perspective. International Journal of Business Administration, $7(5), 49-64$.

Han, H., \& Hyun, S.S. (2012). Image Congruence and Relationship Quality in Predicting Switching Intention: Conspicuousness of Product Use as a Moderator Variable. Journal of Hospitality \& Tourism Research, 29, 448-467.

Hassouna, M., Elyas, T. \& Abou Trab, M. S. (2015). Customer Churn in Mobile Markets: A Comparison of Techniques. International Business Research, 8(6), 224-237. https://doi.org/10.5539/ibr.v8n6p224

Hawkins, D. I., Best, R. J., \& Coney, K. A. (1995). Consumer Behaviour: Building Marketing Strategy. New York: McGraw-Hill.

Hussian, A., Elyas, T. \& Nasseef, O. (2013). Research Paradigms: A Slippery Slope for Fresh Researchers. Life Science Journal, 10(4), 2374-2381.

Hunaiti, Z., Mansour, M., \& Al-Nawafleh. (2009). Electronic Commerce Adoption Barriers in Small and Medium-Sized Enterprises (SMEs) in Developing Countries: The Case of Libya. IBIMA Business Review, 2(5), $37-45$.

Jayawardena, C., Lawlor, F., Grieco, J.C., Savard, M., \& Tarnowski, M. (2013). Challenges and Innovations in Hotel Operations in Canada, Worldwide. Hospitality and Tourism Themes, 5(2), 177-189.

Jeng, J., \& Fesenmaier, D. (2002). Conceptualizing the Travel Decision-Making Hierarchy: A Review of Recent Developments. Tourism Analysis, 7, 15-32. https://doi.org/10.3727/108354202108749925 
Jordan Tourism Board (JTB). (2012). Retrived from http://na.visitjordan.com/visitortoolbar.aspx

Kanaan, R., \& Gharibeh, A. (2013). The Impact of Knowledge Sharing Enablers on Knowledge Sharing Capability: An Empirical Study on Jordanian Telecommunication Firms. European Scientific Journal, 9(22), 237-258.

Kandampully, J., \& Suhartanto, D. (2000).Customer Loyalty in the Hotel Industry: The Role of Customer Satisfaction and Image. International Journal of Contemporary Hospitality Management, 12(6), 346-351.

Kateb, M., Swies, R., \& Maqableh, M. (2015). An Investigation on the Critical Factors of Information System Implementation in Jordanian Information Technology Companies. European Journal of Business and Management, 7(36), 11-28.

Kim, H., Lee, S., Uysal, M., Kim, J., \& Ahn, K. (2015). Nature-Based Tourism: Motivation and Subjective Well-Being. Journal of Travel \& Tourism Marketing, 32(1), 76-96. https://doi.org/10.1080/10548408.2014.997958

Kim, Y., \& Han, H. (2010). Intention to Pay Conventional-Hotel Prices at a Green Hotel-A Modification of the Theory of Planned Behavior. Journal of Sustainable Tourism, 18(8), 997-1014.

Lee, J.S, Hsu, L., T., Han, H., \& Kim, Y. (2010). Understanding How Consumers View Green Hotels: How a Hotel's Green Image Can Influence Behavioural Intentions. Journal of Sustainable Tourism, 18(7), 901-914.

Lee, J.S., Lee, C. K., \& Yoon, Y. (2009). Investigating Differences in Antecedents to Value between First-Time and Repeat Festival-Goers. Journal of Travel \& Tourism Marketing, 26(7), 688-702. https://doi.org/10.1080/10548400903284511

Leung, D., Law, R., Van Hoof, H., \& Buhalis, D. (2013). Social Media in Tourism and Hospitality: A Literature Review. Journal of Travel \& Tourism Marketing, 30(1-2), 3-22. https://doi.org/10.1080/10548408.2013.750919

Loureiro, S., \& González, F. (2008). The Importance of Quality, Satisfaction, Trust, and Image in Relation to Rural Tourist Loyalty. Journal of Travel \& Tourism Marketing, 25(2). https://doi.org/10.1080/10548400802402321

Mahadeen, B., Al-Dmour, R., \& Obeidat, B. Y. (2016). Examining the effect of the Organization's Internal Control System on Organizational Effectiveness: A Jordanian empirical study. International Journal of Business Administration, 7(6), 22-41. https://doi.org/10.5430/ijba.v7n6p22

Maqableh, M., \& Karajeh, H. (2014a). Job Scheduling for Cloud Computing Using Neural Networks. Communications and Network, 6(3), 191. https://doi.org/10.4236/cn.2014.63021

Maqableh, M., \& Karajeh, H. (2014b). A Theoretical Perspective on the Relationship between Leadership Development, Knowledge Management Capability, and Firm Performance. Asian Social Science, 10(6), 128.

Martin, H.S., \& Rodriguez del Bosque, A. I. (2008). Exploring the Cognitive-Affective Nature of Destination Image and the Role of Psychological Factors in its Formation. Tourism Management, 29(2), 263-277.

Masa'deh, R. (2013). The Impact of Information Technology Infrastructure Flexibility on Firm Performance: An Empirical Study of Jordanian Public Shareholding Firms. Jordan Journal of Business Administration, 204-224.

Masa'deh, R., \& Kuk, G. (2009). Antecedents and Intermediaries between Strategic Alignment and Firm Performance. Conference of the Academy of Management Annual Meeting (AOM), Illinois, Chicago, USA.

Masa'deh, R., Gharaibeh, A., Maqableh, M., \& Karajeh, H. (2013a). An Empirical Study of Antecedents and Outcomes of Knowledge Sharing Capability in Jordanian Telecommunication Firms: A Structural Equation Modeling Approach. Life Science Journal, 10(4), 2284-2296.

Masa'deh, R., Hunaiti, Z., \& Bani Yaseen, A. (2008). An Integrative Model Linking IT-Business Strategic Alignment and Firm Performance: The Mediating Role of Pursuing Innovation and Knowledge Management Strategies. Communications of the International Business Information Management Association (IBIMA) Journal, 2(24), 180-187.

Masa'deh, R., Shannak, R., \& Maqableh, M. (2013b). A Structural Equation Modeling Approach for Determining Antecedents and Outcomes of Students' Attitude toward Mobile Commerce Adoption. Life Science Journal, $10(4), 2321-2333$.

Masa'deh, R., Tayeh, M., Al-Jarrah, I., \& Tarhini, A. (2015c). Accounting vs. Market-based Measures of Firm Performance Related to Information Technology Investments. International Review of Social Sciences and Humanities, 129-145.

Masa'deh, R. (2012). The Impact of Management Information Systems (MIS) on Quality Assurance (QA): A Case Study in Jordan. International Journal of Information, Business, and Management, 93-110. 
Masa'deh, R., \& Shannak, R. (2012). Intermediary Effects of Knowledge Management Strategy and Learning Orientation on Strategic Alignment and Firm Performance. Research Journal of International Studies, 112-128.

Masa'deh, R., Gharaibeh, A., \& Obeidat, O. (2015a). Knowledge Sharing Capability: A Literature Review. In Fourth Scientific \& Research Conference on New Trends in Business, Management and Social Sciences, Istanbul, Turkey, 19-20 September 2015 (pp. 1-16). https://doi.org/10.2139/ssrn.2696924

Masa'deh, R., Obeidat, B., \& Al-Dmour, R., (2015b). Knowledge Management Strategies as Intermediary Variables between IT-Business Strategic Alignment and Firm Performance. European Scientific Journal, 11(7), 344-368.

Masa'deh, R., Obeidat, B., \& Tarhini, A. (2016). A Jordanian Empirical Study of the Associations among Transformational Leadership, Transactional Leadership, Knowledge Sharing, Job Performance, and Firm Performance: A Structural Equation Modelling Approach. Journal of Management Development, 35(5), 681-705. https://doi.org/10.1108/JMD-09-2015-0134

Masa'deh, R., Shannak, R., Maqableh, M., \& Tarhini, A. (2017). The Impact of Knowledge Management on Job Performance in Higher Education: The Case of the University of Jordan. Journal of Enterprise Information Management, 30(2), 244-262. https://doi.org/10.1108/JEIM-09-2015-0087

McCleary, K., Weaver, P., \& Hsu, C. (2006). The Relationship between International Leisure Travelers' Origin Country and Product Satisfaction, Value, Service Quality, and Intention to Return. Journal of Travel \& Tourism Marketing, 21(2/3), 117-130.

Mensah, I. (2007). Environmental Management and Sustainable Tourism Development: The Case of Hotels in Greater Accra Region (GAR) of Ghana. Journal of Retail and Leisure Property, 6, 15-22. https://doi.org/10.1057/palgrave.rlp.5100039

Ministry of Tourism and Antiquities (MOTA). (2016). Retrived from http://www.mota.gov.jo/Contents/Statistics.aspx

Nassar, B., \& Arzoky, M. (2015). An Empirical Analysis of the Seasonal Patterns in Aggregate Directors' Trades. International Journal of Economics and Finance, 7(9), 59-84. https://doi.org/10.5539/ijef.v7n9p59

Obeidat, B. Y., Hashem, L., Alansari, I, \& Al-Salti, Z. (2016). The Effect of Knowledge Management Uses on Total Quality Management Practices: A Theoretical Perspective. Journal of Management and Strategy, 7(4), 18-29. https://doi.org/10.5430/jms.v7n4p18

Obeidat, B., Al-Suradi, M., \& Tarhini, A. (2016). The Impact of Knowledge Management on Innovation: An Empirical Study on Jordanian Consultancy Firms. Management Research Review, 39(10), 1214-1238. https://doi.org/10.1108/MRR-09-2015-0214

Obeidat, B., El-Rimawi, S., Maqableh, M., \& Al-Jarrah, I. (2013). Evaluating the Profitability of the Islamic Banks in Jordan. European Journal of Economics, Finance and Administrative Sciences, 56, 27-36.

Obeidat, B., Sweis, R., Zyod, D., \& Alshurideh, M. (2012). The Effect of Perceived Service Quality on Customer Loyalty in Internet Service Providers in Jordan. Journal of Management Research, 4(4), 224-242. https://doi.org/10.5296/jmr.v4i4.2130

Obeidat, B.Y., Al-Sarayrah, S., Al-Salti, Z., \& Sweis, R. (2016). Cultural Influence on Strategic Human Resource Management Practices: A Jordanian case study. International Business Research, 9(10), 94-114.

Obeidat, B.Y., Tarhini, A., \& Aqqad, N. (2017). The impact of intellectual capital on innovation via the mediating role of knowledge management: A structural equation modeling approach. International Journal of Knowledge Management Studies, 8(2), 15-33.

Oliver, R. L. (1999). Whence Consumer Loyalty? Journal of Marketing, 63(4), 33-44. https://doi.org/10.2307/1252099

Orozco, J., Tarhini, A., \& Masa'deh, R. (2015). A framework of IS/business alignment management practices to improve the design of IT Governance architectures. International Journal of Business and Management, 10(4), 1-12. https://doi.org/10.5539/ijbm.v10n4p1

Pallant, J. (2005). SPSS Survival Manual: A Step Guide to Data Analysis Using SPSS for Windows Version 12. Chicago, Illinois: Open University Press.

Ranaweera, C., \& Prabhu, J. (2003). On the Relative Importance of Customer Satisfaction and Trust as Determinants of Customer Retention and Positive Word-of-Mouth. Journal of Targeting, Measurement and Analysis for Marketing, 12(1), 82-89. https://doi.org/10.1057/palgrave.jt.5740100

Reinartz, W.J., \& Kumar, V. (2002). The Mismanagement of Customer Loyalty. Harvard Business Review, 80(7), 
86-94.

Ribbink, D., Van Riel, A., Liljander, V., \& Streukens, S. (2004). Comfort Your Online Customer: Quality, Trust and Loyalty on the Internet. Managing Service Quality: An International Journal, 14(6), 446-456.

Sasidharan, V., Sirakaya, E., \& Kerstetter, D. (2002). Developing Countries and Tourism Ecolabels. Tourism Management, 23, 161-174. https://doi.org/10.1016/S0261-5177(01)00047-4

Sekaran, U., \& Bougie, R. (2013). Research Methods for Business: A Skill-Building Approach (6th ed.). New York: Wiley.

Shannak, R., \& Akour, M. (2012). Knowledge Management Strategy Building: Literature Review. European Scientific Journal, 8(15), 143-168.

Shannak, R., \& Almajali, D. (2010). Information Technology Investments: A Literature Review. Proceedings of the 14th IBIMA Conference on Global Business Transformation through Innovation and Knowledge Management: An Academic Perspective, Istanbul-Turkey, 23rd-24th June, pp.1356-1368.

Shannak, R., Al-Zu'bi, Z., Alshurideh, M., \& Altamony, H. (2012a). A Theoretical Perspective on the Relationship between Knowledge Management Systems, Customer Knowledge Management, and Firm Competitive Advantage. European Journal of Social Sciences, 32(4), 520-532.

Shannak, R., Obeidat, B., \& Masa'deh, R. (2012b). Culture and the Implementation Process of Strategic Decisions in Jordan. Journal of Management Research, 4(4), 257-281. https://doi.org/10.5296/jmr.v4i4.2160

Smith, E. (2000). E-Loyalty: How to Keep Customers Coming Back to Your Website, Harper Collins.

Tarhini, A., Al-Badi, A., Almajali, M., \& Alrabayaah, S. H. (2017). Factors influencing employees' Intention to use Cloud Computing. Journal of Management \& Strategy, 8(2), 47-62. https://doi.org/10.5430/jms.v8n2p47

Tarhini, A., Elyas, T., Akour, M. A. \& Al-Salti, Z. (2016). Technology, Demographic Characteristics and E-Learning Acceptance: A Conceptual Model Based on Extended Technology Acceptance Model. Higher Education Studies, 6(3), 72-89. https://doi.org/10.5539/hes.v6n3p72

Tarhini, A., El-Masri, M., Ali, M., \& Serrano, A. (2016). Extending the UTAUT model to understand the customers' acceptance and use of internet banking in Lebanon: A structural equation modeling approach. Information Technology and People, 29(4), 830-849. https://doi.org/10.1108/ITP-02-2014-0034

Tarhini, A., Arachchilage, N., \& Abbasi, M. (2015). A Critical Review of Theories and Models of Technology Adoption and Acceptance in Information System Research. International Journal of Technology Diffusion, 6(4), 58-77. https://doi.org/10.4018/IJTD.2015100104

Tarhini, A., Mgbemena, C., AbouTrab, M.S., \& Masa'deh, R. (2015). User Adoption of Online Banking in Nigeria: A Qualitative study. Journal of Internet Banking and Commerce, 20(3), 1-8.

Tarhini, A., Mohammed, A., \& Maqableh, M. (2016). Modeling Factors Affecting Student's Usage Behaviour of E-Learning Systems in Lebanon. International Journal of Business and Management, 11(2), 299-314. https://doi.org/10.5539/ijbm.v11n2p299

Tepeci, M. (1999). Increasing Brand Loyalty in Hospitality Industry. International Journal of Contemporary Hospitality Management, 11(5), 223-230. https://doi.org/10.1108/09596119910272757

Tsaur, S, H., Lin, C, T., \& Wu, C, S. (2005). Cultural Differences of Service Quality and Behavioral Intention in Tourist Hotels. Journal of Hospitality \& Leisure Marketing, 13(1), 41-63. https://doi.org/10.1300/J150v13n01_04

Tsoukatos, E., \& Rand, G, K. (2006). Path Analysis of Perceived Service Quality, Satisfaction and Loyalty in Greek Insurance. Managing Service Quality: An International Journal, 16(5), 501-519. https://doi.org/10.1108/09604520610686746

Turnbull, P., \& Wilson, D. T. (1989). Developing and Protecting Profitable Customer Relationships. Industrial Marketing Management, 18, 233-238. https://doi.org/10.1016/0019-8501(89)90040-0

Vratskikh, I., Al-Lozi, M., \& Maqableh, M. (2016). The Impact of Emotional Intelligence on Job Performance via the Mediating Role of Job Satisfaction. International Journal of Business and Management, 69-91. https://doi.org/10.5539/ijbm.v11n2p69

Yoon, Y., \& Uysal, M. (2005). An Examination of the Effects of Motivation and Satisfaction on Destination Loyalty: A Structural Model. Tourism Management, 26(1), 45-56. https://doi.org/10.1016/j.tourman.2003.08.016 